\section{TECHNOLOGICAL EDUCATION IN THE U.S.S.R.}

Soviet Technological Curricula

Translated from the Original Russian by Dr. C. R. S. Manders. Pp. xiii + 391. (London: Sir Isaac Pitman and Sons, Ltd., 1963.) 110s. net.

$\triangle$ DVANCED and underdeveloped nations alike are preoccupied with the application of science and technology under the stimulus of economic necessity and political pressures. The supply of educated and welltrained scientists and technologists and in sufficient numbers has thus become a matter of the first importance. The pressures in the West have been greatly increased by the spectacular achievements of the U.S.S.R. in space technology, but no less in informed circles by the increasing output of a highly organized industry in the markets of the world. Interest in the Soviet educational system as the basis of these great achievements at the end of a brief space of 40 years of planned development is profound. Dr. Manders's translation of the Soviet Technological Curricula, with his supplementary information, is a most important and timely service to all concerned with technological education.

The curricula are divided into 16 groups corresponding to branches of the national economy, and each group comprises a different number of 'specialty' studies in courses of 5 or 5.5 years' duration. Altogether the book contains 166 'specialty' in particular technologies and branches of agriculture. The curriculum of each specialization is not narrowly set but provides the specialist training for some contiguous branches of industry or agriculture. The content and scope of the theoretical and applied subjects in the first three-year period are common for all specialities of each group. Study is required of a foreign language throughout the courses; for the first higher degree (candidate-Ph.D. equivalent) two foreign languages are needed, and three for the second higher degree (doctorate -D.Sc. equivalent).

In the book, each curriculum covers two large pages in tabular form, divided into the following main sections: "Timetable", which shows how every week of the student year is utilized; "Study Plan", which sets out the subjects by hours, courses and semesters, and specifies examinations, tests, course projects and course papers; "Specializations", which are given in similar detail; "Optional Subjects"; "Practical Instruction"; "Industrial Practical Work"; "Diploma Project or Paper"; and "State Examinations". Similar curricular analyses are given in an appendix for applied mathematics, physics, pure mathematics and chemistry.

In terms of Soviet planning, the necessity for such a clearly regulated system is seen in the fact that in 1959-60 there were $2,260,000$ students attending 738 higher educa. tional establishments. Of these, 40 are universities, which, however, provide training in basic subjects only, and nothing of an applied nature. The total includes 184 higher educational establishments for technologies and 109 for agriculture to which these tables apply. Uniformity, or an assured minimum coverage and standard of study, facilitates movement in such a large training programme of students to other institutions over a vast area for research and further study for higher degrees.

Examination of these curricula provokes many questions about the disposition of time between lectures and practical work, the balance of pure and applied subjects, the degree of specialization and the amount of industrial training in later years and so on. The details given are for 1955-56, and a later analysis (prepared as soon as possible) for 1962-63 would make a most interesting contrast. During this period, for example, the Soviet authorities have been experimenting with the sandwich-course system of education and training. Bearing in mind the increasing difficulties in obtaining training places for sandwich courses in
Britain in the past two years, a comparison with a scheme being established in a country where both education and industry are regulated by the State would be very interesting.

The curricula are preceded by an order of the Minister of Higher Education requiring the introduction of substan. tial courses through several years of the "History of the Communist Party of the Soviet Union", "Political Economy", and "Dialectical and Historical Materialism", For indoctrination or interpretation? What might be said in the U.S.S.R. if Britain had by analogy 'The History of Government in Britain and the Commonwealth'. 'Political Economy', and 'The Philosophy and Practice of Western Democracy', if we exercised ourselves to provide them? Are the implications of matters of such fundamental importance to the practising scientist and technologist to be caught not taught when he is a student? The incorporation of general/liberal studies in all courses for the Diploma in Technology was surely a move in the right direction.

The final question is: How has this plan been applied in such detail with such evident success? The answer is worth reading in view of the publication of the report of the Robbins Committee and the great expansion this should engender in higher education. Dr. Manders states that "Since the U.S.S.R. was formed its leaders have clearly recognized that science and technology are essential means for the realization of the national aims. In furtherance of their policy they have all along ploughed back a generous proportion of their trained manpower into teaching at all grades .... [in higher educational establishments] in the U.S.S.R. there is no teacher supply problem".

Copies of this invaluable book should be in every university and college library, consulted by all those devising curricula for new developments or making essential revisions, not for slavish imitation, but for the stimulation it will provide. Dr. Manders is to be warmly thanked for his work, and the Department of Scientific and Industrial Research for supporting this publication. In the period of change ahead, the Department of Seientific and Industrial Research and the Ministry of Education could very usefully follow this up by sponsoring a series of similar analyses of curricula in other countries, perhaps with more discussion of their significance for future developments in Britain. Peter F. R. Venables

\section{INSECT PHYSIOLOGY}

Advances in Insect Physiology

Vol. 1. Edited by J. W. L. Beament, J. E. Treherne and V. B. Wigglesworth. Pp. xiii +512 . (London and New York: Academic Press, 1963.) 105s.

THE Agricultural Research Council Unit of Insect Physiology at Cambridge has long occupied a leading position in this subject. Prof. Wigglesworth and his two colleagues, having themselves initiated many new lines of enquiry into insect physiology, have now put biologists in their debt by promoting a reviewing journal which should make it easier to keep in touch with work on this group of animals. In their preface the editors list some of the aspects of physiology which have been studied in insects in the past twenty years and which are presumably to be covered by articles in subsequent volumes. They include the chemistry of natural products, the dynamic biochemistry of intermediary metabolism, the fine structure and biophysics of cells and their parts, electrophysiology of nerve and muscle, ionic and osmotic regulation, physiological genetics and Entwicklungsmechanik, the role of hormones and neurohumours, the mechanism of sensory perception, the physiological basis of behaviour, and the contribution of all this physio. logical knowledge to the understanding of ecology. This 